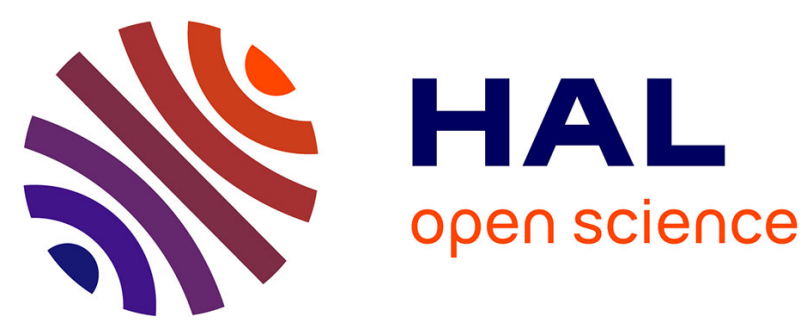

\title{
Thermally and electrochemically driven topotactical transformations in sodium layered oxides NaxVO2
}

Christophe Didier, Marie Guignard, Matthew R. Suchomel, Dany Carlier, Jacques Darriet, Claude Delmas

\section{- To cite this version:}

Christophe Didier, Marie Guignard, Matthew R. Suchomel, Dany Carlier, Jacques Darriet, et al.. Thermally and electrochemically driven topotactical transformations in sodium layered oxides NaxVO2. Chemistry of Materials, 2016, 28 (5), pp.1462-1471. 10.1021/acs.chemmater.5b04882 . hal-01288011

\section{HAL Id: hal-01288011 \\ https://hal.science/hal-01288011}

Submitted on 15 Jan 2021

HAL is a multi-disciplinary open access archive for the deposit and dissemination of scientific research documents, whether they are published or not. The documents may come from teaching and research institutions in France or abroad, or from public or private research centers.
L'archive ouverte pluridisciplinaire HAL, est destinée au dépôt et à la diffusion de documents scientifiques de niveau recherche, publiés ou non, émanant des établissements d'enseignement et de recherche français ou étrangers, des laboratoires publics ou privés. 


\title{
Thermally and Electrochemically Driven Topotactical Trans- formations in Sodium Layered Oxides $\mathrm{Na}_{\mathrm{x}} \mathrm{VO}_{2}$
}

\author{
Christophe Didier $^{1,2}$, Marie Guignard ${ }^{1,2 *}$, Matthew R. Suchomel ${ }^{3 \dagger}$, Dany Carlier $^{1,2}$, Jacques Darriet $^{1,2}$, \\ Claude Delmas ${ }^{1,2}$
}

${ }^{1}$ CNRS, ICMCB, 87 avenue du Dr A. Schweitzer, 33608 Pessac Cedex, France, ${ }^{2}$ Université de Bordeaux, ICMCB, 87 avenue du Dr A. Schweitzer, 33608 Pessac Cedex , France. ${ }^{3}$ Argonne National Laboratory, Advanced Photon Source, Lemont, Illinois 60439, USA

\begin{abstract}
Phase diagrams and structural transformations in the complex $\mathrm{Na}_{\mathrm{x}} \mathrm{VO}_{2}$ system have been studied using electrochemical (de)intercalation and in situ and operando high resolution synchrotron powder diffraction. Starting from $\mathrm{O}^{\prime} 3-\mathrm{Na}_{1 / 2} \mathrm{VO}_{2}$ obtained by sodium electrochemical deintercalation of $\mathrm{O} 3-\mathrm{NaVO}_{2}$, the structural details of irreversible and reversible thermally driven transformations to P'3 and P3 type structures are presented. Subsequently, these P' $3-\mathrm{Na}_{\mathrm{x}} \mathrm{VO}_{2}$ phases provide a platform for operando studies exploring the $\mathrm{Na}_{\mathrm{x}} \mathrm{VO}_{2}$ phase diagram as a function of sodium electrochemical (de)intercalation. In this system, three single phase domains have been found: a line phase $\mathrm{P}^{\prime} 3-\mathrm{Na}_{1 / 2} \mathrm{VO}_{2}$, one solid solution for $0.53 \leq x \leq 0.55$ characterized by an incommensurate modulated structure and a second solid solution for $0.63 \leq x \leq 0.65$ with a defective structure resulting from a random stack of O'3 and P'3 layers. With further sodium intercalation $(x>0.65)$, the structure irreversibly transforms to the starting parent phase $\mathrm{O} 3-\mathrm{NaVO}_{2}$. This work reveals new details about the diverse structural polymorphs found in sodium layered oxides used as electrode battery materials and the transitional pathways between them as a function of temperature and composition.
\end{abstract}

\section{Introduction}

Sodium layered oxides were first examined for use as positive electrode materials in the early 1980's, but become overshadowed in following years by more commercially successful Liion based technologies. However, lately there is again renewed focus on the $\mathrm{Na}$ layered oxide systems $\left(\mathrm{Na}_{\mathrm{x}} \mathrm{MO}_{2}\right.$, where $M$ can be a single $3 \mathrm{~d}$ cation, or a mixture of several $3 \mathrm{~d}$ cations, or a mixture of a $3 \mathrm{~d}$ cation and magnesium) both for their unusual electronic properties and for potential energy storage applications, where the low cost and abundance of sodium makes them attractive candidates for economical large-scale batteries. Several studies have revealed rich and complex phase diagrams in these systems, as typified by $\mathrm{Na}_{\mathrm{x}} \mathrm{CoO}_{2}$, which is marked by multiple interslab ordering arrangements of $\mathrm{Na}$ cations located in octahedral and prismatic coordination environments. ${ }^{1-5}$ Other members of the $\mathrm{Na}_{x} \mathrm{MO}_{2}$ family also exhibit phase diagrams equaling fascinating, but are often less well understood. For example, challenging synthetic approaches are required to produce layered phases in the $\mathrm{Na}_{\mathrm{x}} \mathrm{VO}_{2}$ system $(0.5<\mathrm{x}<1)$, on which a limited number of studies on phase pure compositions have examined their physical properties ${ }^{6-9}$ and prospects as electrode candidates in sodium batteries. ${ }^{10-12}$ In the $\mathrm{Na}_{\mathrm{x}} \mathrm{VO}_{2}$ system only two phases $\mathrm{O} 3-\mathrm{NaVO}_{2}{ }^{13}$ and $\mathrm{P} 2-\mathrm{Na}_{\sim 0.7} \mathrm{VO}_{2}{ }^{6}$ can be obtained by classical hightemperature solid-state chemistry synthesis. These phases are described by a letter prefix on the chemical formula specifying octahedral $(\mathrm{O})$ or prismatic $(\mathrm{P})$ coordination of $\mathrm{Na}$ cations and a number indicating the quantity of $\mathrm{MO}_{6}$ octahedral layers within the unit cell (e.g. O3 or P2, see reference ${ }^{14}$ for full details on the nomenclature of layered structures). All other compositions in the $\mathrm{Na}_{\mathrm{x}} \mathrm{VO}_{2}$ system are metastable and their synthesis requires the use of room temperature sodium deintercalation/intercalation reactions. Previously, we have discovered two new metastable phases in the $\mathrm{Na}_{\mathrm{x}} \mathrm{VO}_{2}$ system for $x=1 / 2$ and $x=2 / 3$ by the use of electrochemical deintercalation from the parent $\mathrm{O} 3-\mathrm{NaVO}_{2}$ compound in a battery cell. ${ }^{10}$ Both new phases possess a O'3 structure type, which differs from the $\mathrm{O} 3$ type due to a monoclinic distortion (denoted by the apostrophe) of the $R-3 m$ hexagonal cell usually used to describe layered oxides with the $\alpha-\mathrm{NaFeO}_{2}$ structure. (The relationship between hexagonal and monoclinic cells is described further in the Supporting Information).

To more fully unravel the complex $\mathrm{Na}$ layered oxide phase diagrams, it is critical to understand transitional paths between these diverse structural arrangements. For a majority of $\mathrm{NaMO}_{2}$ compositions containing $3 d$ transition metal cations (for $\mathrm{M}=\mathrm{Cr}, \mathrm{Mn}$, $\mathrm{Co}, \mathrm{Ni}$ ), sodium electrochemical deintercalation from the parent $\mathrm{O} 3-\mathrm{NaMO}_{2}$ initially induces a small shift of $\mathrm{MO}_{2}$ layers formed by edge-sharing $\mathrm{MO}_{6}$ octahedra which leads to a distortion of the oxygen lattice, resulting in a monoclinic O'3-structure type. The octahedral environment for the sodium ions is preserved. This is illustrated in Figure 1. With continued electrochemical deintercalation, additional gliding of the $\mathrm{MO}_{2}$ slabs gives rise to a monoclinic P'3-structure type containing trigonal prismatic environments for the remaining sodium ions. ${ }^{15-18}$ Both these transitions require only small atomic displacements, with no $\mathrm{M}-\mathrm{O}$ broken bonds, low activation energies (i.e. reactions may occur at room temperature) and minimal changes in unit cell volume. These transitions can thus be described as topotactical reactions as defined by Shannon and Rossi. ${ }^{19}$ Topotactical transformations as described above for $\mathrm{NaMO}_{2}$ have been observed in several sodium layered oxide systems which demonstrate reasonable properties as positive electrode materials in sodium batteries: such as the binary systems $\mathrm{Na}_{\mathrm{x}}(\mathrm{Mn}, \mathrm{Ni}) \mathrm{O}_{2},{ }^{20} \mathrm{Na}_{\mathrm{x}}(\mathrm{Fe}, \mathrm{Co}) \mathrm{O}_{2}{ }^{21}$ or $\mathrm{Na}_{\mathrm{x}}(\mathrm{Fe}, \mathrm{Ni}) \mathrm{O}_{2},{ }^{22}$ and in ternary or in quaternary systems. ${ }^{23,24}$ 


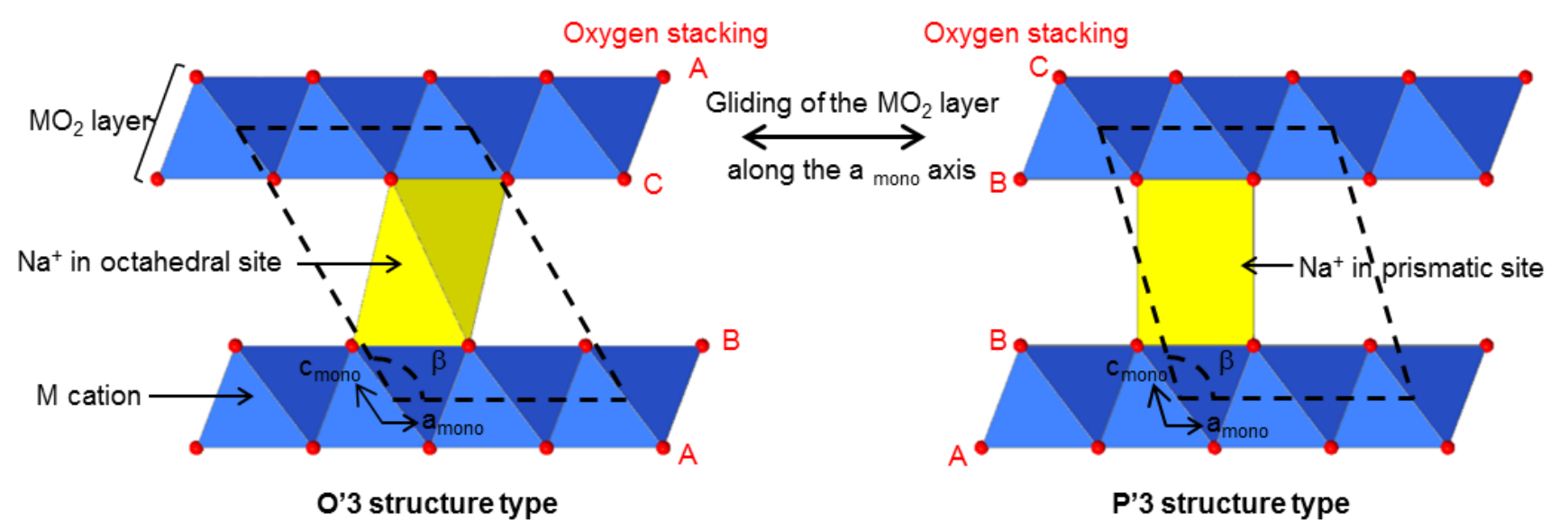

Figure 1. Schematic view of the gliding of the $\mathrm{MO}_{2}$ layers occurring during the sodium electrochemical intercalation/deintercalation resulting in the O'3 $\leftrightarrow$ P'3-structure type transition. The projection along the $\mathrm{b}$ axis of the monoclinic cell is drawn with a black dashed line.

By contrast, $\mathrm{MO}_{2}$ slab gliding between the O'3 and P'3 structure types is not observed with sodium electrochemical deintercalation at ambient temperatures for $\mathrm{O} 3-\mathrm{NaTiO} 2^{25}$ or $\mathrm{O} 3-\mathrm{NaVO}_{2}{ }^{10}$ Instead the sodium ions remain in octahedral O'3 sites. This was explained in recent theoretical calculations by the instability of $\mathrm{P} 3-\mathrm{Na}_{1 / 2} \mathrm{VO}_{2}$ and $\mathrm{P} 3-\mathrm{Na}_{1 / 2} \mathrm{TiO}_{2}$ compared to $\mathrm{O} 3-\mathrm{Na}_{1 / 2} \mathrm{VO}_{2}$ and $\mathrm{O} 3-\mathrm{Na}_{1 / 2} \mathrm{TiO}_{2}$ structure types, respective1y. ${ }^{26}$ However, alternative routes to the P'3 structure type are still possible. Our group showed in a previous study that a $\mathrm{P}^{\prime} 3-\mathrm{Na}_{\mathrm{x}} \mathrm{VO}_{2}$ structure for $\mathrm{x} \sim 0.60$ could be obtained by chemical sodium deintercalation from the parent $\mathrm{O} 3-\mathrm{NaVO}_{2}$ followed by a heat treatment at $200^{\circ} \mathrm{C}$. $^{27}$

Structural transitions across the compositional and temperature phase space of layered $\mathrm{Na}$ oxide systems are linked to changes in physical properties and their performance in electrochemical applications. The phase diagrams of $\mathrm{Na}_{\mathrm{x}} \mathrm{MO}_{2}$ structures are typically more complex than is found in widely used Li based materials. Therefore, future advances on $\mathrm{Na}$ based battery technologies can be strongly impacted by our understanding of the diverse structural prototypes found within these materials and the transitional pathways between them as a function of temperature and composition (i.e. sodium deintercalation). In this paper, we describe a detailed examination of the O3/O'3 $\leftrightarrow$ P'3/P3 structures and the associated thermally or electrochemically driven topotactical transformation pathways in the $\mathrm{Na}_{\mathrm{x}} \mathrm{VO}_{2}$ system. Electrochemical and diffraction probes, including in situ and operando synchrotron powder diffraction, have been used to obtain structural models and to clarify reversible and irreversible pathways in $\mathrm{Na}_{\mathrm{x}} \mathrm{VO}_{2}$ driven both by temperature (e.g. O'3 to P'3 type) and sodium electrochemical intercalation (e.g. P'3 to O'3). These results not only elucidate our view of this complex $\mathrm{Na}_{\mathrm{x}} \mathrm{VO}_{2}$ system, but also serve as a template for greater understanding of other equally rich layered $\mathrm{Na}$ oxide systems.

\section{Experimental section}

\subsection{Synthesis}

The parent $\mathrm{O} 3-\mathrm{NaVO}_{2}$ phase was prepared in a gold crucible by chemical reduction of precursor $\mathrm{NaVO}_{3}$ powder under $\mathrm{H}_{2}$ atmosphere at $700^{\circ} \mathrm{C}$ for 8 hours. The precursor $\mathrm{NaVO}_{3}$ had been previously synthesized by solid-state reaction of a stoichiometric mixture of $\mathrm{Na}_{2} \mathrm{CO}_{3}$ (purity above $99.9 \%$ ) and $\mathrm{V}_{2} \mathrm{O}_{5}$ (purity above $99.9 \%$ ) by heating in a gold crucible at $600^{\circ} \mathrm{C}$ for 12 hours. Three single-phase $\mathrm{Na}_{\mathrm{x}} \mathrm{VO}_{2}$ samples were ob- tained by sodium electrochemical deintercalation in a battery from $\mathrm{O} 3-\mathrm{NaVO}_{2}$ for the compositions with $\mathrm{x}=1 / 2,0.55$ and $2 / 3$. This electrochemical synthesis was realized in a sodium battery with the following electrochemical chain: metal $\mathrm{Na}$ | $\mathrm{NaClO}_{4}(1 \mathrm{M})$ in propylene carbonate $\mid \mathrm{O} 3-\mathrm{NaVO}_{2}$. A pellet of the $\mathrm{O} 3-\mathrm{NaVO}_{2}$ compound was sintered at $600^{\circ} \mathrm{C}$ for $24 \mathrm{~h}$ and it was used as the positive electrode. The battery was galvanostatically charged at a $\mathrm{C} / 100$ rate $\left(1 \mathrm{e}^{-}\right.$per vanadium transferred in 100 hours) up to $2.45 \mathrm{~V}, 2.27 \mathrm{~V}$ and $1.92 \mathrm{~V}$; corresponding to the Fermi level (vs. the $\mathrm{Na}^{+} / \mathrm{Na}$ couple) for the O'3- $\mathrm{Na}_{1 / 2} \mathrm{VO}_{2}$, O'3 $-\mathrm{Na}_{0.55} \mathrm{VO}_{2}$ and O'3- $\mathrm{Na}_{2 / 3} \mathrm{VO}_{2}$ compositions, respectively. ${ }^{28}$ Once the appropriate voltage was reached, it was held and continuously applied to the electrochemical cell while monitoring the potentiostatic charge current. When the current drops to zero, the electrochemical reaction is complete and a pure sample of the expected material is obtained. For samples investigated in this work, a constant voltage was held for $\sim 50$ additional hours (after reaching zero current) in order to ensure optimal equilibrium conditions in the materials. Once complete, the equilibrium pellet was recovered, washed with dimethyl carbonate and dried under vacuum. Note that all the $\mathrm{Na}_{\mathrm{x}} \mathrm{VO}_{2}$ phases are highly sensitive to humidity and/or oxygen and therefore must always be handled under argon in a glove-box. Furthermore each characterization has been realized under an argon atmosphere.

\subsection{Characterization}

Preliminary laboratory based X-ray powder diffraction measurements (Panalytical X'Pert Pro with $\mathrm{Cu}$-source) on the synthesized $\mathrm{Na}_{\mathrm{x}} \mathrm{VO}_{2}$ samples did not provide sufficient sensitivity of critical weak intensity diffraction peaks required to understand the different complex structural motifs connected by topotactical transformations in this system. For this reason, high-resolution synchrotron powder diffraction probes with superior signal-to-noise sensitivity were used in this study, both at the ID31 beamline of the European Synchrotron Radiation Facility (ESRF) (for in situ variable temperature measurements) and at the 11-BM beamline of the Advanced Photon Source (APS) at Argonne National Laboratory (for operando electrochemical measurements). Jana2006 software was used to refine either the profile of the experimental diagram and to determine the unit cell parameters, and the modulation wave in the case of incommensurate modulated structure, using the Le Bail method or the structure of $\mathrm{O}^{\prime} 3-\mathrm{Na}_{1 / 2} \mathrm{VO}_{2}$ using the 
Rietveld method. ${ }^{29}$ At beamline ID31, in situ diffraction pat-

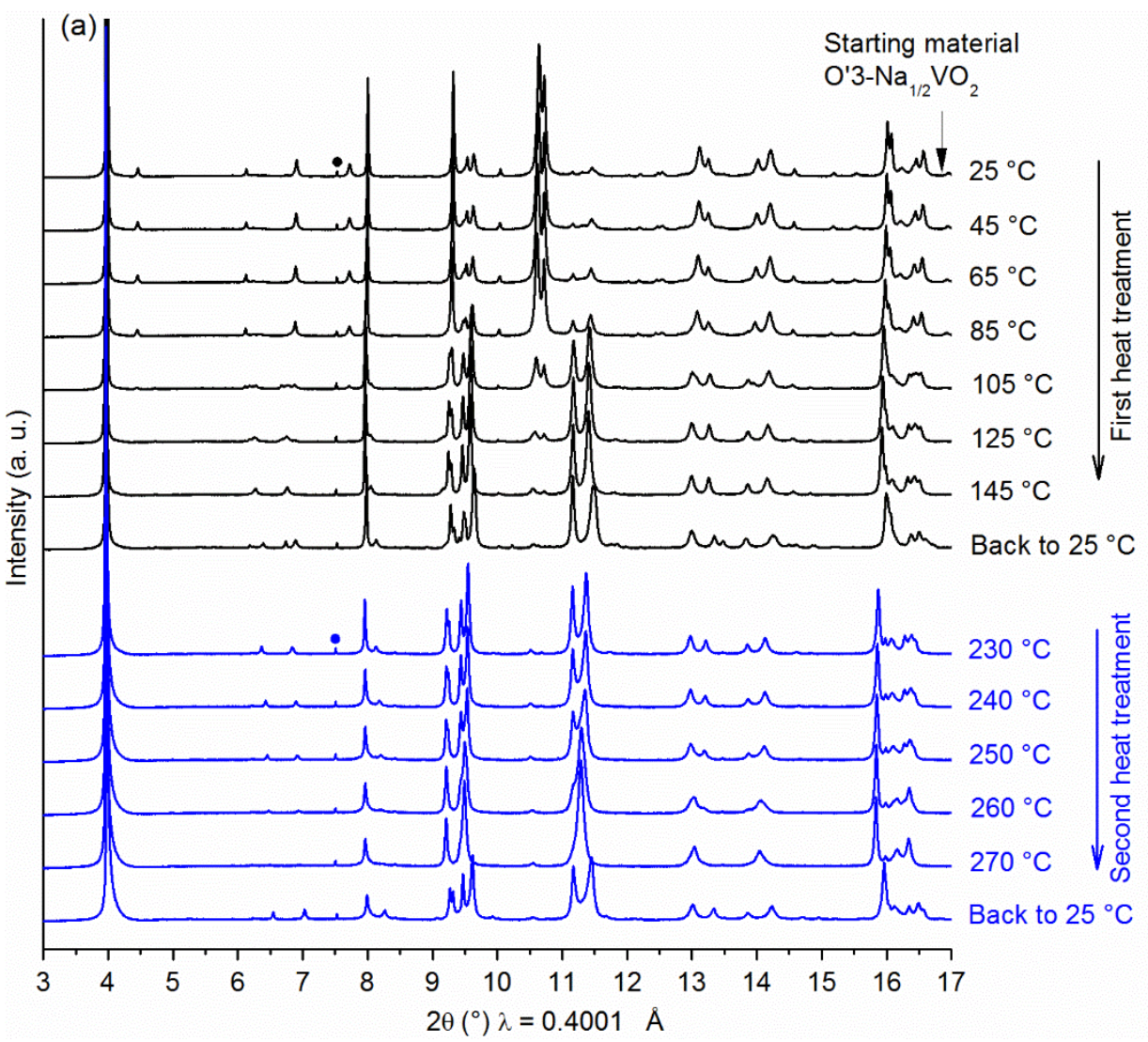

(b)

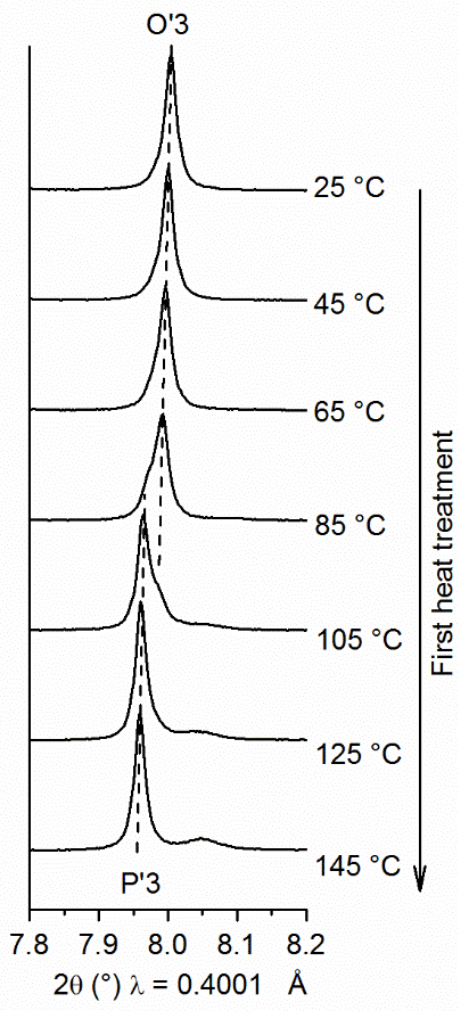

Figure 2. (a) In situ high resolution X-ray powder diffraction recorded at ID31 beamline (ESRF) starting from $\mathrm{O}^{\prime} 3-\mathrm{Na}_{1 / 2} \mathrm{VO}_{2}$ during the first heat treatment (in black) and during the second heat treatment (in blue) (b) Zoom of the diffraction patterns recorded during the first heat treatment. The main diffraction peak of $\mathrm{a}_{2} \mathrm{O}_{3}$ impurity is topped by a circle $(\bullet)$.

were recorded as a function of temperature from $25^{\circ} \mathrm{C}$ to $270^{\circ} \mathrm{C}$ over the $2 \theta$-range of $0-55^{\circ}$ using a $0.001^{\circ}$ step size and incident wavelength of $\lambda=0.4001 \AA$ on a spinning $1-\mathrm{mm}$ diameter glass capillary sealed under argon. At beamline 11$\mathrm{BM}$, electrochemical operando powder diffraction studies were performed on $\mathrm{Na}_{\mathrm{x}} \mathrm{VO}_{2}$ based sodium batteries that were charged and discharged at a rate of $\mathrm{C} / 100$ ( $1 \mathrm{e}^{-}$per vanadium transferred in $100 \mathrm{~h}$ ). Scans were recorded on a modified 2032 type coin cell at $25^{\circ} \mathrm{C}$ over a $0-28^{\circ} 2 \theta$-range using a $0.001^{\circ}$ step size and incident wavelength of $\lambda=0.4136 \AA$. Small $(\approx 3$ $\mathrm{mm}$ diameter) pierced openings in the modified coin cells were covered by gas tight sealed Kapton windows to increase $\mathrm{X}$-ray transmission. $\mathrm{Na}_{\mathrm{x}} \mathrm{VO}_{2}$ powder was mixed with a graphite/carbon-black powder and PTFE to form the positive electrode. A thin $(\approx 100 \mu \mathrm{m})$ stainless steel foil was used as the positive electrode current collector to ensure both robust electronic contact with the entire electrode as well as a high X-ray beam transparency. A thin foil of Na metal $(\approx 200 \mu \mathrm{m})$ used as the negative electrode was also highly transparent to the highenergy X-ray probe $(\approx 30 \mathrm{keV})$ used in this experiment. Samples for ex situ galvanostatic cycling experiments were also prepared using $\mathrm{Na}_{\mathrm{x}} \mathrm{VO}_{2}$ powders mixed with graphite/carbonblack powder and PTFE to form the positive electrode in battery cells.

\section{Results \& Discussion}

\subsection{Thermally activated transitions}

Thermally driven topotactic transitions in the $\mathrm{Na}_{\mathrm{x}} \mathrm{VO}_{2}$ phase diagram are described first. Preliminary investigations on the
O'3- $\mathrm{Na}_{1 / 2} \mathrm{VO}_{2}, \mathrm{O}^{\prime} 3-\mathrm{Na}_{0.55} \mathrm{VO}_{2}$ and O'3 $-\mathrm{Na}_{2 / 3} \mathrm{VO}_{2}$ compositions prepared by sodium electrochemical deintercalation revealed an O'3 $\rightarrow$ P'3 transition after heating to $200{ }^{\circ} \mathrm{C}$ for only the $\mathrm{x}$ $=1 / 2$ and $\mathrm{x}=0.55$ compositions. For larger values of $\mathrm{x}$, in the O'3- $\mathrm{Na}_{2 / 3} \mathrm{VO}_{2}$ material, no structural change upon heating was observed. This is consistent with previous studies showing a similar transitional pathway after heating at $200{ }^{\circ} \mathrm{C}$ for the $\mathrm{x} \approx$ 0.6 composition. ${ }^{27}$ For clarity we report here in the present paper only the full details of this structural transition for $\mathrm{x}$ $=1 / 2$ in the $\mathrm{O}^{\prime} 3-\mathrm{Na}_{1 / 2} \mathrm{VO}_{2}$ composition.

In situ synchrotron powder diffraction recorded at beamline ID31 (Figure 2) reveals the structural evolution of $\mathrm{Na}_{1 / 2} \mathrm{VO}_{2}$ phases as a function of temperature between $25{ }^{\circ} \mathrm{C}$ and 270 ${ }^{\circ} \mathrm{C}$. The top pattern is that of O' $3-\mathrm{Na}_{1 / 2} \mathrm{VO}_{2}$ recorded at $25{ }^{\circ} \mathrm{C}$. A structural refinement using the Rietveld method of these 25 ${ }^{\circ} \mathrm{C}$ high-resolution powder diffraction data shows very good agreement with the room temperature model determined previously from laboratory $\mathrm{X}$-ray diffraction data. ${ }^{28}$ This model confirms that sodium electrochemical deintercalation from the rhombohedral $\mathrm{O} 3-\mathrm{NaVO}_{2}$ (Space group: $R-3 m$ ) at ambient temperature induces a small distortion of the hexagonal cell resulting in a monoclinic O'3-type structure for $\mathrm{Na}_{1 / 2} \mathrm{VO}_{2}$ (Space group: $C 2 / c$ ). The refined structural model obtained for O'3- $\mathrm{Na}_{1 / 2} \mathrm{VO}_{2}$ using the Rietveld method and the data recorded at beamline ID31 is given in the Supporting Information. In this monoclinic cell, sodium ions occupy half the octahedral sites available between the $\mathrm{VO}_{2}$ layers made of edge-sharing $\mathrm{VO}_{6}$ octahedra in a perfectly ordered way to 
form zigzag chains along c-axis. This ordering explains the appearance of small superstructure diffraction peaks in the $2 \theta$ range $4.2-7.9^{\circ}$. Additional details of the monoclinic distortion and how it is manifested in the synchrotron powder diffraction data are shown in the Supporting Information.

In situ temperature studies of $\mathrm{Na}_{1 / 2} \mathrm{VO}_{2}$ were realized in two steps for this study. Initially the $\mathrm{O}^{\prime} 3-\mathrm{Na}_{1 / 2} \mathrm{VO}_{2}$ sample was heated to $145^{\circ} \mathrm{C}$ and then cooled back down to room temperature (black patterns in Figure 2a). Subsequently, the powder sample was re-heated to the higher temperature of $270^{\circ} \mathrm{C}$ and cooled back down to $25^{\circ} \mathrm{C}$ (blue patterns in Fig. 2a).

During the first heating of O' $3-\mathrm{Na}_{1 / 2} \mathrm{VO}_{2}$ to $145^{\circ} \mathrm{C}$, additional diffraction peaks that can associated with a $\mathrm{P}$ '3 phase first appear at $\sim 85^{\circ} \mathrm{C}$ as a shoulder on the peak around $\sim 7.97^{\circ}$ (Figure 2b). At $105{ }^{\circ} \mathrm{C}$, the two phases still coexist but the new P' 3 phase is now predominant. The transition of O'3 to P'3 is complete around $145^{\circ} \mathrm{C}$, as indicated by an inversion of intensity for diffraction peaks in the $10.5^{\circ}-11.6^{\circ} 2 \theta$-range. As described previously, ${ }^{30}$ the split $\left(\begin{array}{lll}1 & 0 & 4\end{array}\right)$ reflection peaks (at $2 \theta=10.64^{\circ}$ and $10.72^{\circ}$ in Figure 2) are more intense than the pair of split (l $\left.\begin{array}{lll}1 & 0 & 5\end{array}\right)$ reflection peaks (at $2 \theta=11.30^{\circ}$ and $11.46^{\circ}$ ) for the $\mathrm{O}^{\prime} 3-\mathrm{Na}_{1 / 2} \mathrm{VO}_{2}$ structure. It was shown that the reversal of this intensity ratio indicates a new phase crystallizing in a P'3-type structure (See Figure S1 for an indexation of the hexagonal cell). At $145{ }^{\circ} \mathrm{C}$, all small superstructure diffraction peaks characteristic of $\mathrm{O}^{\prime} 3-\mathrm{Na}_{1 / 2} \mathrm{VO}_{2}$ (for example approximately at $2 \theta=6.1,7.7$ and $10.0^{\circ}$ in Figure 2) are suppressed; whereas new small peaks appearing at $2 \theta=6.27$, 6.76 and 8.05 can be indexed using the $\mathrm{C} 2 / \mathrm{m}(0 \beta 0) \mathrm{s} 0$ superspace group previously proposed for $\mathrm{P}^{\prime} 3-\mathrm{Na}_{\sim 0.6} \mathrm{VO}_{2}{ }^{27} \mathrm{~A}$ refinement using this superspace group performed against these in situ data at $145{ }^{\circ} \mathrm{C}$ gives the unit cell parameters $a=4.9982(4) \AA, \quad b=2.8793(3) \AA, \quad c=5.9349(7) \AA$, $\beta=104.68(1)^{\circ}$, and the modulation wave vector $\mathbf{q}=0.478(1) \mathbf{b}^{*}$.

These refined unit cell parameters for $\mathrm{P}^{\prime} 3-\mathrm{Na}_{\sim 1 / 2} \mathrm{VO}_{2}$ are in general agreement with ambient temperature values previously reported $\mathrm{P}^{\prime} 3-\mathrm{Na}_{\sim 0.6} \mathrm{VO}_{2},{ }^{27}$ with some variance as expected from the different measurement temperatures and sodium content. In particular, changes in the modulation $\mathrm{q}$ vector can be associated with differences in sodium content, and - as discussed below - it is difficult to know precisely the Na content in the absence of electrochemical measurements. Incommensurate modulated structures are commonly found in layered compounds, including sodium layered oxides. ${ }^{2,3,27,31,32}$ They can usually be described as composite crystals based on two interpenetrating periodic systems that are mutually incommensurate. ${ }^{33}$ In $\mathrm{Na}_{\mathrm{x}} \mathrm{VO}_{2}$ crystals, one lattice is formed by $\mathrm{VO}_{2}$ layers and the other by $\mathrm{Na}^{+}$ions show ordering between $\mathrm{VO}_{2}$ layers. Therefore, as the sodium content is varied in these systems, the periodicity of the lattice formed by $\mathrm{Na}^{+}$ions varies and resulting modulation wave vector $\mathrm{q}$ is also altered.

After the initial heating to $145^{\circ} \mathrm{C}$, the sample was cooled to ambient temperature at a moderate rate. Interestingly, the in situ diffraction data (Figure 2) show the P'3-type structure is maintained indicating that thermally activated O'3 $\rightarrow$ P'3 transition is irreversible for the composition $\mathrm{Na}_{1 / 2} \mathrm{VO}_{2}$. A close inspection of the $25{ }^{\circ} \mathrm{C}$ data recorded after the initial heating finds that some diffraction peaks cannot be indexed using the same cell used to index the pattern at $145^{\circ} \mathrm{C}$ : for example at $6.74^{\circ}$ (corresponding to an interplanar distance $\mathrm{d}$ of $3.403 \AA)$ and $10.22^{\circ}(\mathrm{d}=2.244 \AA)$. Based on a careful study of these data, plus electrochemical results presented below in this paper, we conclude that the P' 3 phase observed at $145{ }^{\circ} \mathrm{C}$ has in fact segregated into two phases on cooling: $\mathrm{P}^{\prime} 3-\mathrm{Na}_{1 / 2} \mathrm{VO}_{2}$ and P'3-Na ${ }_{\sim 0.55} \mathrm{VO}_{2}$. Segregation into these phases can be understood if the true $\mathrm{Na}: \mathrm{V}$ ratio in the parent powder is slightly greater than the targeted 1:2 value. This could be the consequence of minor sodium impurities (e.g. unreacted sodium carbonate or unwashed $\mathrm{NaClO}_{4}$ salt from the electrolyte) coexisting and reacting with the $\mathrm{O}$ '3 $-\mathrm{Na}_{1 / 2} \mathrm{VO}_{2}$ phase on heating. However, in this scenario, an unexpected partial reduction of vanadium would also be required in addition to elevated sodium content in order to explain the coexistence of both $\mathrm{P}^{\prime} 3-\mathrm{Na}_{\sim 0.55} \mathrm{VO}_{2}$ and $\mathrm{P}^{\prime} 3-\mathrm{Na}_{1 / 2} \mathrm{VO}_{2}$. Given that in situ heating was realized within a capillary sealed under argon, oxygen release associated with vanadium reduction could occur; additional investigation is required to clarify this detail. In any case, global $\mathrm{Na}$ content in $\mathrm{Na}_{\sim \mathrm{X}} \mathrm{VO}_{2}$ powder samples can be controlled precisely using electrochemical methods, as demonstrated by operando studies described later in this work.

Subsequent additional in situ heating of the same powder sample, as shown in Figure 2, reveals again a single homogenous phase diffraction pattern at $230{ }^{\circ} \mathrm{C}$ that can be fit using an incommensurate P'3 unit cell with the parameters $a=$ 5.0159(6) $\AA, b=2.8903$ (4) $\AA, c=5.945(1) \AA, \beta=104.90(1)^{\circ}$, $\mathbf{q}=0.458(1) \mathbf{b}^{*}$. The existence of a single phase indicates that the phase diagram in the $\mathrm{P}^{\prime} 3-\mathrm{Na}_{\mathrm{x}} \mathrm{VO}_{2}$ might be different at room temperature than above $100^{\circ} \mathrm{C}$. With continued heating up to $270{ }^{\circ} \mathrm{C}$ many split peaks merge (for example see the $2 \theta$ ranges: $9.1-9.3^{\circ}, 9.4-9.6^{\circ}, 11.0-11.6^{\circ} 12.7-13.4^{\circ}$ or 13.8 14.4) and weak reflections resulting from sodium ordering

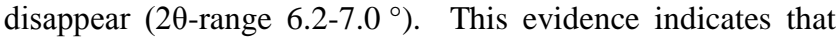
sodium mobility at this temperature is high enough to impede ordering between the $\mathrm{VO}_{2}$ layers. The structure of $\mathrm{Na}_{\sim 1 / 2} \mathrm{VO}_{2}$ at $270{ }^{\circ} \mathrm{C}$ is therefore transformed to a more symmetric structure, and its diffraction pattern can be indexed using the space group $R 3 m$ that is usually used to describe sodium layered oxides with undistorted P3-type structure. This phenomenon was already observed in a very similar material: P'3$\mathrm{Na}_{\sim 0.62} \mathrm{CoO}_{2} \cdot{ }^{34}$ After the powder is cooled down to ambient temperature the second time from $270^{\circ}$, the pattern recorded at $25^{\circ} \mathrm{C}$ can be indexed using the $\mathrm{P}^{\prime} 3$ superspace group $C 2 / m(0 \beta 0) s 0$ indicating a reversible $\mathrm{P}^{\prime} 3 \leftrightarrow \mathrm{P} 3$ transition pathway as observed in $\mathrm{P}^{\prime} 3-\mathrm{Na}_{\sim 0.62} \mathrm{CoO}_{2} \cdot{ }^{34}$ However, one observes in Figure 2 that the diffraction pattern recorded at 25 ${ }^{\circ} \mathrm{C}$ after the second heat treatment is not exactly the same as that recorded at $25^{\circ} \mathrm{C}$ after the first heat treatment. Firstly, it shows the existence of the phase with the incommensurate modulated structure only. Also, the refined modulation wave vector $\mathrm{q}$ for this phase has slightly changed $\left(\mathbf{q}=0.461(1) \mathbf{b}^{*}\right.$ at $25{ }^{\circ} \mathrm{C}$ after the first heat treatment, $\mathbf{q}=0.432(1) \mathbf{b}^{*}$ after the second heat treatment) and additional anisotropic broadening of the diffraction peaks at 4 and $8^{\circ}$ is clearly visible towards higher angles with a decrease of their intensity. We propose that these changes in the diffraction pattern reflect a high degree of defects in the structure. Layered oxide phases obtained by chemical or electrochemical alkali deintercalation are usually metastable. The heat treatment at $270{ }^{\circ} \mathrm{C}$ likely induces structural rearrangements in the material that mark the start of a transformation into a more thermodynamically stable compound(s) at higher temperature. The formation of defects could be a first step towards a complete transformation. The 
existence of multiple phases with slightly different lattice parameters could also explain the anisotropic broadening of these diffraction peaks.

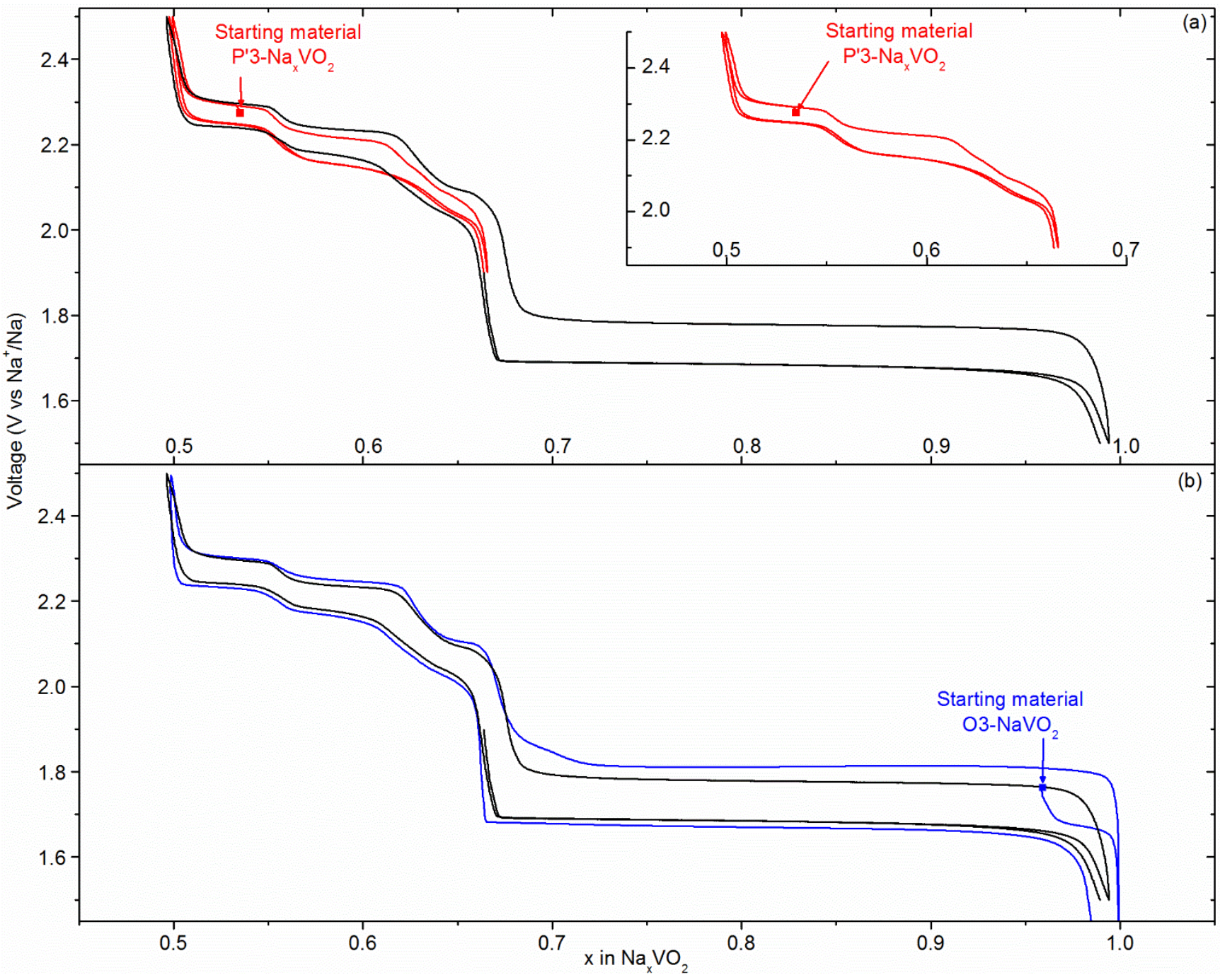

Figure 3. Evolution of cell voltage as a function of the sodium content of sodium batteries (a) made with $\mathrm{P}^{\prime} 3-\mathrm{Na}_{\mathrm{x}} \mathrm{VO}_{2}$ at the positive electrode first cycled between 1.9 and $2.5 \mathrm{~V}$ (in red) and then between 1.5 and $2.5 \mathrm{~V}$ (in black) and (b) made with $\mathrm{P}^{\prime} 3-\mathrm{Na}_{\mathrm{x}} \mathrm{VO}_{2}$ (in black) and $\mathrm{O} 3-\mathrm{NaVO}_{2}$ (in blue) cycled between 1.5 and $2.5 \mathrm{~V}$.

\subsection{Evolution of cell voltage under galvanostatic cycling}

As described above, topotactic transitions - both reversible and irreversible - between O'3, P'3 and P3 structure types can be driven in the $\mathrm{Na}_{\mathrm{x}} \mathrm{VO}_{2}$ system by temperature. But it is also critically important to understand the $\mathrm{Na}_{\mathrm{x}} \mathrm{VO}_{2}$ phase diagram as a function of $\mathrm{Na}$ composition and electrochemical potential, as these structural transformations will profoundly effect the properties and performance of any battery technology incorporating these or similar layered $\mathrm{Na}$ materials. In our study reported here, this aspect was examined using ex situ electrochemical and operando synchrotron powder diffraction experiments described below. In particular, we find that the O'3 structure type (irreversibly transformed to P'3 type on heating) can be recovered by electrochemical intercalation via a complex path involving different types of mixed stacking defect arrangements.

Prior to performing operendo synchrotron experiments, cell voltage evolution as a function of sodium content was examined in battery prepared using a $\mathrm{P}^{\prime} 3-\mathrm{Na}_{\mathrm{x}} \mathrm{VO}_{2}$ based positive electrode. Subsequent to the findings of our thermal investiga- tions, this powder of the $\mathrm{P}^{\prime} 3-\mathrm{Na}_{\mathrm{x}} \mathrm{VO}_{2}$ structure type was obtained by heat treatment of $\mathrm{O}^{\prime} 3-\mathrm{Na}_{1 / 2} \mathrm{VO}_{2}$ at $200^{\circ} \mathrm{C}$ for 24 hours, which itself had been derived by electrochemical deintercalation from a starting $\mathrm{O} 3-\mathrm{NaVO}_{2}$ sample. As mentioned above, the precise sodium content in the P'3$\mathrm{Na}_{\mathrm{x}} \mathrm{VO}_{2}$ material was tuned by analogy with the reported electrochemical properties of $\mathrm{O}^{\prime} 3-\mathrm{Na}_{1 / 2} \mathrm{VO}_{2}{ }^{28}$ By assuming that a voltage jump occurring between $2.3 \mathrm{~V}$ and $2.5 \mathrm{~V}$ is characteristic of the existence of the single P' $3-\mathrm{Na}_{1 / 2} \mathrm{VO}_{2}$ phase with sodium content $\mathrm{x}=1 / 2$, the sodium content and chemical composition of the starting P' $3-\mathrm{Na}_{\mathrm{x}} \mathrm{VO}_{2}$ material was thus determined to be $\mathrm{Na}_{\sim 0.53} \mathrm{VO}_{2}$.

The evolution of cell voltage as a function of the sodium content is shown in Figure 3(a). For the first cycle (shown as a red line in Figure 3a), starting with a $\mathrm{P}^{\prime} 3-\mathrm{Na}_{0.53} \mathrm{VO}_{2}$ type positive electrode powder, the battery was charged up to $2.5 \mathrm{~V}$, discharged down to $1.9 \mathrm{~V}$, again charged back up to $2.5 \mathrm{~V}$, and finally discharged again to $1.9 \mathrm{~V}$. Over this voltage range (2.5 - $1.9 \mathrm{~V}$, for $1 / 2<\mathrm{x}<2 / 3)$, electrochemical curves overlay 
exactly and thus sodium (de)intercalation is found to be completely reversible with a complex electrochemical profile due to the occurrence of multiple reversible phase transitions in P'3- $\mathrm{Na}_{\mathrm{x}} \mathrm{VO}_{2}$ occurring during the electrochemical process. To explore the cell behavior over a wider voltage range (shown as a black line in Figure 3a), the cell galvanostatic potential of the same cell was
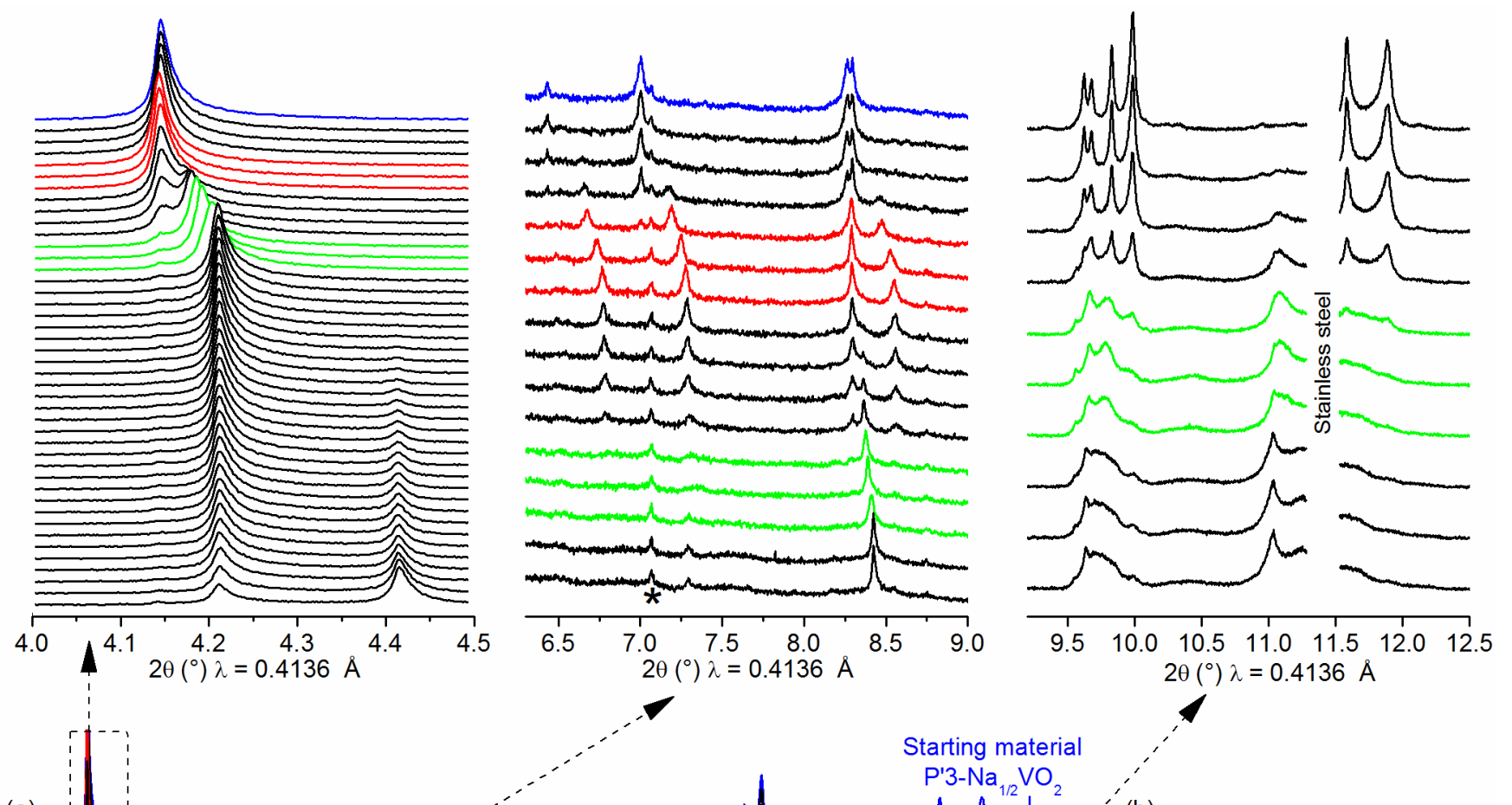

(a)
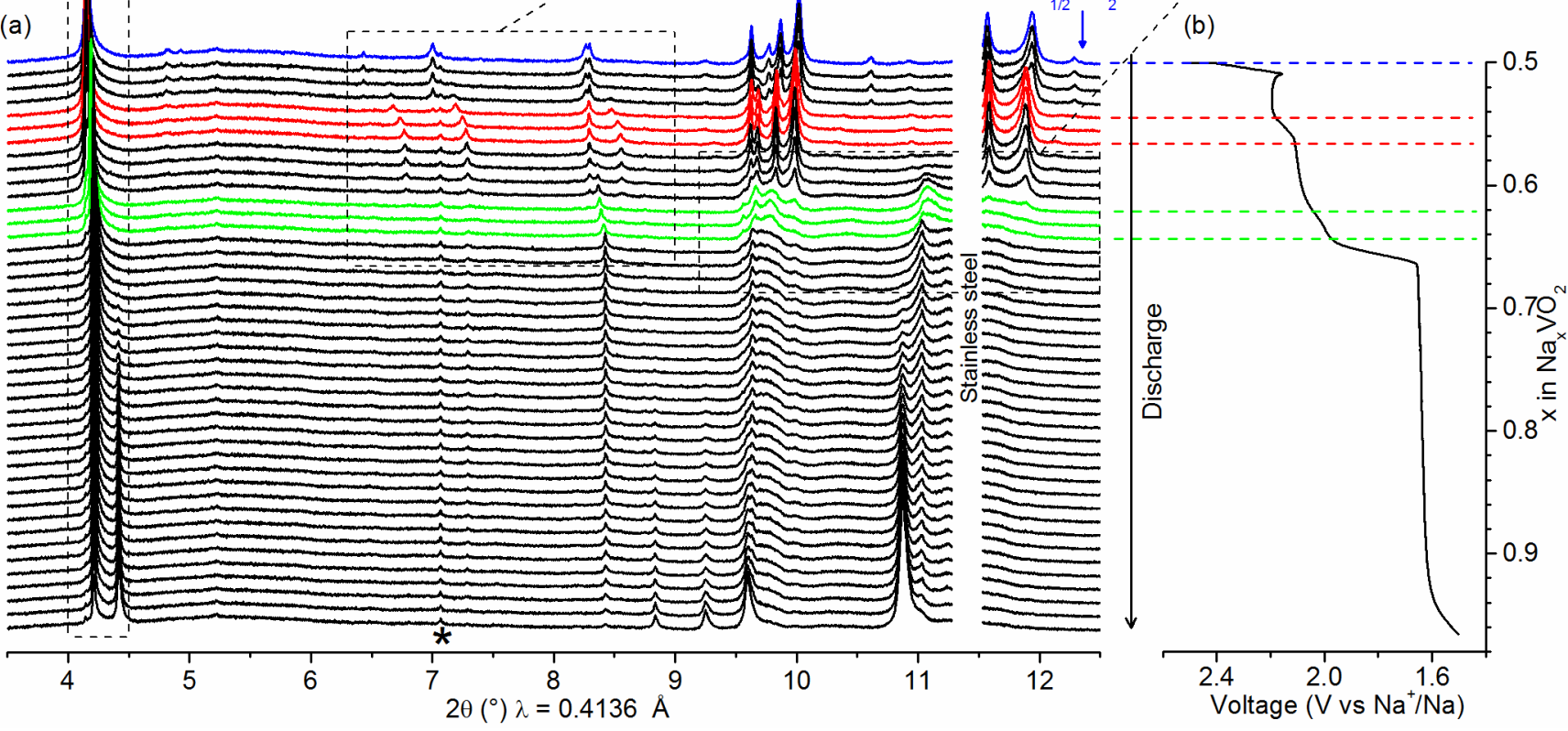

Figure 4. (a) In situ high resolution X-ray powder diffraction recorded at $11-\mathrm{BM}$ beamline (APS) starting from $\mathrm{P}^{\prime} 3-\mathrm{Na}_{1 / 2} \mathrm{VO}_{2}$ during the sodium electrochemical intercalation. One-phase domains are highlighted in blue, red and green. (b) Evolution of the cell voltage of the sodium battery as a function of the sodium content recorded during the diffraction experiment (the overshooting phenomenon observed at the beginning of the discharge comes from the low conductivity of the starting material $\left.\mathrm{P}^{\prime} 3-\mathrm{Na}_{1 / 2} \mathrm{VO}_{2}\right)$. The main diffraction peak of the

graphite additive is notified

then further decreased (from $1.9 \mathrm{~V}$ ) down to $1.5 \mathrm{~V}$. The cell was then next cycled from $1.5 \mathrm{~V}$, up to $2.5 \mathrm{~V}$, and back down to $1.5 \mathrm{~V}$. At the end of the final discharge, the sodium amount intercalated in the positive electrode material was allowed to reach the composition $\mathrm{Na}_{\sim 1} \mathrm{VO}_{2}$. Note that this value, determined from the electrochemical curve, is compatible the maximum amount of sodium ions that can be intercalated in this material using a slow $\mathrm{C} / 100$ rate, and is consistent with our determination of the initial P' $3-\mathrm{Na}_{0.53} \mathrm{VO}_{2}$ composition.

Looking closely to the electrochemical behavior in sodium range $1 / 2 \leq x \leq 2 / 3$, we can see that the measured curves on cycling between $2.5-1.9 \mathrm{~V}$ (red line in Figure 3a) and between 2.5 - $1.5 \mathrm{~V}$ (black line) are broadly similar but not exactly equivalent. For example, the average voltage measured 
on the red curve in the compositional range $0.56<\mathrm{x}<0.61$ is lowered by $\sim 0.02 \mathrm{~V}$, and similarly polarization for the red curve is reduced over the $0.62<\mathrm{x}<0.66$ compositional range. A different electrochemical profile is observed for voltages below $1.9 \mathrm{~V}$, when the battery is discharged down to $1.5 \mathrm{~V}$, where a large plateau is measured over the compositional range $2 / 3 \leq x<1$. This behavior is very similar to that observed during the electrochemical deintercalation from O3$\mathrm{NaVO}_{2} .{ }^{10}$ To compare more directly with the behavior of $\mathrm{O} 3-$ $\mathrm{NaVO}_{2}$, in Figure $3 \mathrm{~b}$ we overlay the electrochemical curve recorded from the battery studied in this work initially based on P' $3-\mathrm{Na}_{0.53} \mathrm{VO}_{2}$ (black line, same data in both Figures $3 \mathrm{a}$ and $3 \mathrm{~b}$ ), to that recorded on a battery initially incorporating an $\mathrm{O} 3$ $\mathrm{NaVO}_{2}$ based positive electrode (blue line Figure 3b). Although not overlaying perfectly, these two curves show very similar profiles and features at matching voltage and sodium content values. Based on this comparison, we have surmised that a $\mathrm{P}^{\prime} 3-\mathrm{Na}_{\mathrm{x}} \mathrm{VO}_{2}$ structure in this phase diagram is maintained only over the $1.9-2.5 \mathrm{~V}$ voltage range for the $1 / 2 \leq x \leq 2 / 3$ compositional range, whereas a new structural transition from P'3 to $\mathrm{O} 3$ occurs when the voltage falls below $1.9 \mathrm{~V}$ for compositions with $\mathrm{x}>2 / 3$.

\subsection{Electrochemically activated transitions}

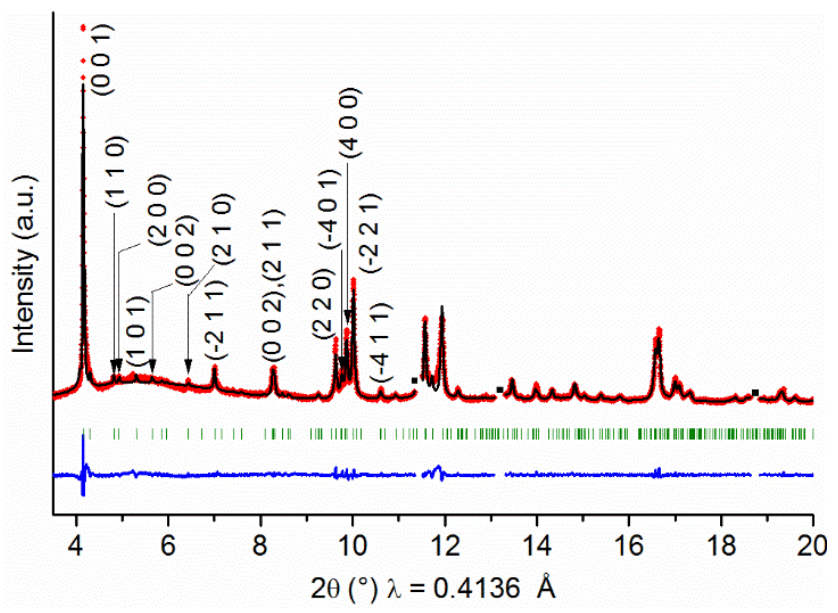

Figure 5. Experimental high resolution X-ray powder diffraction pattern of $\mathrm{P}^{\prime} 3-\mathrm{Na}_{1 / 2} \mathrm{VO}_{2}$ recorded at 11-BM beamline (APS) in the sodium battery (red diamonds), calculated pattern obtained from the LeBail refinement (black line) and difference line (blue line). Green bars show the position of the Bragg reflections. Missing data topped by a square ( $\boldsymbol{\square})$ correspond to stainless steel diffraction peaks.

To confirm this hypothesis and elucidate further details of the $\mathrm{Na}_{\mathrm{x}} \mathrm{VO}_{2}$ phase diagram, an ambient temperature operando synchrotron powder diffraction experiment was performed at beamline 11-BM of the APS examining the discharge cycle of a similarly constructed battery using $\mathrm{P}^{\prime} 3-\mathrm{Na}_{\mathrm{x}} \mathrm{VO}_{2}$ as the positive electrode material. As discussed above, the cell was initially charged up to $2.5 \mathrm{~V}$ in order to achieve the pure homogenous P' $3-\mathrm{Na}_{1 / 2} \mathrm{VO}_{2}$ composition. Figure 4 shows the highresolution synchrotron powder diffraction patterns recorded on discharge. The first scan recorded at a potential of $2.5 \mathrm{~V}$ (uppermost pattern in Figure 4a) blue corresponds to P'3$\mathrm{Na}_{1 / 2} \mathrm{VO}_{2}$, and can be indexed using a non-modulated $P 2_{1} / m$ cell four times larger than the $C 2 / m$ cell previously used to P'3-type structure. ${ }^{30}$ Figure 5 shows the profile fit to these data of a refined $P 2{ }_{1} / m$ unit cell with the parameters $a=9.894(9) \quad \AA, \quad b=5.736(6) \quad \AA, \quad c=5.881(6) \AA$, $\beta=103.61(3)^{\circ}$. A fully refined structural model of P'3$\mathrm{Na}_{1 / 2} \mathrm{VO}_{2}$ is not reported here but it will be given in an upcoming paper. However, note that this unit cell is different from other reported polymorphs of $\mathrm{Na}_{1 / 2} \mathrm{VO}_{2}$ (e.g, P2 and O'3) displaying clear superstructure ordering of $\mathrm{Na}^{+}$ions and vacancies between the $\mathrm{MO}_{2}$ layers, ${ }^{12,28}$ and different from the $C 2 / m(0 \beta 0) s 0$ modulated P'3-type structure measured by in situ powder diffraction at the ESRF in this study for the composition $\mathrm{x} \sim 0.53$. This new $P 2_{1} / m$ unit cell allows us to index additional weak peaks visible on the $\mathrm{X}$-ray diffraction pattern at $25^{\circ} \mathrm{C}$ after the thermally activated O'3 $\rightarrow$ P'3 transition. For example, peaks mentioned in Section 3.1 observed at $3.403 \AA$ and $2.244 \AA$ correspond to the $\left(\begin{array}{lll}-2 & 1 & 1\end{array}\right)$ and $\left(\begin{array}{lll}-4 & 1 & 1\end{array}\right)$ reflections of $\mathrm{P}^{\prime} 3-\mathrm{Na}_{1 / 2} \mathrm{VO}_{2}$, respectively.

\subsubsection{Reversible transformations}

On the initial voltage discharge of the P' $3-\mathrm{Na}_{1 / 2} \mathrm{VO}_{2}$ based battery during the operando synchrotron measurement, the intensity of diffraction peaks associated with $\mathrm{P}^{\prime} 3-\mathrm{Na}_{1 / 2} \mathrm{VO}_{2}$ decreases and new peaks appear, for example at 6.66 and 7.17 ${ }^{\circ}$ shown in Figure 4a. This demonstrates the existence of a biphasic domain in the $\mathrm{Na}_{\mathrm{x}} \mathrm{VO}_{2}$ phase diagram over the compositional range $1 / 2<x \leq 0.54$ involving two phases with P'3type structure, and is in good agreement with the voltage plateau observed at $2.20 \mathrm{~V}$ on the electrochemical curve.

With further voltage discharge, for the compositional range $0.55 \leq \mathrm{x} \leq 0.57$, a solid solution-domain is observed in which the P'3-structure type is maintained. Powder diffraction patterns of the phases belonging to this solid solution, shown in red in Figure 4(a), are characterized by small diffraction peaks shifting toward high angles as $\mathrm{Na}^{+}$ions are intercalated into the structure while the angular position of main diffraction peaks remain unchanged. This behavior suggests the existence of a structural modulation with a wave vector $\mathbf{q}$ which is varying as a function of sodium content. The three diffraction patterns of the phases belonging to this solid solution but with different sodium content were indexed using the superspace group $C 2 / m(0 \beta 0) s 0$ and the cell parameters of their structure were refined. The refined cell parameters of the structure of the three phases are given in Table 1, as a function of their chemical composition estimated from the electrochemical curve (Figure 4(b)). It is noticeable that a very simple relationship exists between the sodium content, $x$ the modulation wave vector, $\mathbf{q}$, and the reciprocal axis vector, $\mathbf{b}^{*}: \mathbf{q} \approx(1-\mathrm{x})$ b*. A similar relationship was found in $\mathrm{Na}_{\mathrm{x}} \mathrm{CoO}_{2}$ incommensurate crystals for sodium content in the $0.42<x<0.68$ compositional range. ${ }^{31}$ This indicates that the layered structure can accommodate extra $\mathrm{Na}^{+}$ions, within a small $\mathrm{x}$-range, to provide the best arrangement for $\mathrm{Na}^{+}$ions that minimizes electrostatic repulsions between two nearest-neighbors alkaline ions. The limit of existence of the solid solution with an incommensurate structure in the $\mathrm{x}$-range $0.55 \leq \mathrm{x} \leq 0.57$ indicates that the phase co-existing with $\mathrm{P}^{\prime} 3-\mathrm{Na}_{1 / 2} \mathrm{VO}_{2}$ at $25^{\circ} \mathrm{C}$ after the thermally activated O'3 $\rightarrow$ P'3 transition must be P'3$\mathrm{Na}_{\sim 0.55} \mathrm{VO}_{2}$. This is in agreement with the value of the modulation wave vector $q$ obtained from the refinement of the cell parameters from the X-ray diffraction data $\left(\mathbf{q}=0.461(1) \mathbf{b}^{*}\right)$.

With continued voltage discharge, for $0.57<\mathrm{x}<0.62$, the small diffraction peaks arising from the structural modulation stop shifting and their intensity decreases. Moreover, new peaks appear indicating that a new biphasic domain exists in this sodium content $\mathrm{x}$-range. Continuing to larger compositions of $\mathrm{x}$, between $0.62 \leq \mathrm{x} \leq 0.65$, the continuous shifting of 
the diffraction peaks around $4.2^{\circ}$ and $8.3^{\circ}$ shows that the three diffraction patterns (plotted in green in Figure 4(a)) belong to the same solid solution. Surprisingly, the peaks in the $9.5-$ $12.5^{\circ} 2 \theta$-range are very broad for single phases with an inversion of intensities in the $2 \theta$-range from $11^{\circ}$ to $12^{\circ}$. This inversion of intensities tends to show that the $\mathrm{MO}_{2}$ layers glide again to give rise to a electrochemically activated $\mathrm{P}^{\prime} 3 \rightarrow \mathrm{O}^{\prime} 3$ transition as an opposite

Table 1. Refined cell parameters in the superspace group $\mathrm{C} 2 / \mathrm{m}(0 \beta 0) s 0$ from in situ high resolution diffraction patterns recorded during the sodium electrochemical intercalation. Chemical composition deduced from the electrochemical curve is given for each pattern.

\begin{tabular}{|l|l|l|l|l|l|}
\hline $\begin{array}{l}\text { Chemical } \\
\text { composition }\end{array}$ & $\mathrm{a}(\AA)$ & $\mathrm{b}(\AA)$ & $\mathrm{c}(\AA)$ & $\beta\left(^{\circ}\right)$ & $\mathrm{q}$ \\
\hline $\mathrm{Na}_{\sim 0.55} \mathrm{VO}_{2}$ & $4.981(1)$ & $2.869(1)$ & $5.906(2)$ & $104.38(1)$ & $0.452(1)$ \\
\hline $\mathrm{Na}_{\sim 0.56} \mathrm{VO}_{2}$ & $4.987(1)$ & $2.873(1)$ & $5.911(2)$ & $104.32(2)$ & $0.443(1)$ \\
\hline $\mathrm{Na}_{\sim 0.57} \mathrm{VO}_{2}$ & $4.989(1)$ & $2.874(1)$ & $5.910(2)$ & $104.35(2)$ & $0.437(1)$ \\
\hline
\end{tabular}

inversion was observed during the thermally activated O'3 $\rightarrow$ P'3 transition (Figure 2). Moreover, looking closely at the position of the diffraction peaks around $4.2^{\circ}$ and $8.3^{\circ}$ both related to the interlayer distance, one can see that it is shifted towards higher angles for the diffraction patterns plotted in green compared to that of the ones plotted in red. This indicates that the interlayer distance is shorter in the solid solution with a sodium content range $0.62 \leq x \leq 0.65$ than that in the solid solution with an incommensurate P'3-type structure in the $\mathrm{x}$-range $0.55 \leq \mathrm{x} \leq 0.57$. The decrease of the interlayer distance can be explained by the P' $3 \rightarrow$ O'3 transition, sodium ions occupying smaller octahedral sites in the O'3-type structure. However, the broadening of the diffraction peaks in this region (green patterns in Figure 4(a)) suggests that this gliding is not fully cooperative. Stacking faults may exist in the $\mathrm{Na}_{\mathrm{x}} \mathrm{VO}_{2}$ phases associated with these diffraction patterns. In these phases, we propose that the oxygen packing is neither a perfect succession $\mathrm{ABBCCA}$... layers (giving rise to the P'3type structure) nor of $\mathrm{ABCABC} \ldots$ layers (giving rise to the O'3-type structure). Instead, we suggest that the structure of $\mathrm{Na}_{\mathrm{x}} \mathrm{VO}_{2}$ phases here is an intergrowth of the O'3- and P'3-type structures.

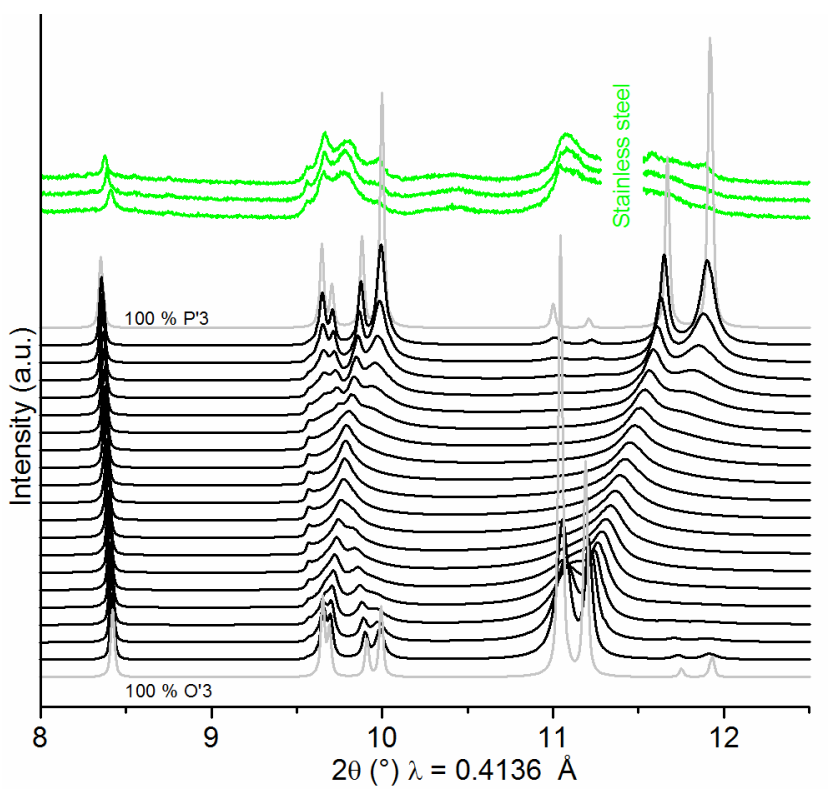

Figure 6. Experimental high resolution X-ray powder diffraction pattern of $\mathrm{P}^{\prime} 3-\mathrm{Na}_{\sim 0.63} \mathrm{VO}_{2}$ recorded at $11-\mathrm{BM}$ beamline (APS) in the sodium battery (green lines) and those simulated by DIFFaX.

In order to test our proposition of P'3-type stacking defects in the O'3-type structure, we have used DIFFaX software ${ }^{35}$ to simulate the X-ray diffraction pattern of $\mathrm{Na}_{\sim 0.63} \mathrm{VO}_{2}$ whose experimental diffraction pattern is presented in Figure 6 (intermediate green pattern in the solid solution). We considered that the structure of this phase could be described as a random stack of layers of O'3- and P'3-type structures. In the simulation, we started from a pure P'3-type structure (whose diffraction pattern corresponds to the top grey pattern in Figure 6) and random layers of sodium ions in an octahedral environment were gradually added to the structure to replace layers of sodium ions in prismatic sites. The final structure (bottommost grey pattern in Figure 6) is the O'3-type one, where all the layers of sodium ions in prismatic sites have been replaced by layers of sodium ions in octahedral sites. The simulated X-ray diffraction patterns of select starting, intermediate and final structures are shown in Figure 6. Although none of the simulated X-ray diffraction pattern matches perfectly with the experimental data, our DIFFAX simulations do show how remaining P'3-type stacking defects in the O'3-type structure can reasonably explain broadening of the diffraction peaks in this system. A more elaborated model taking into account the key role of stacking history in determining the fault probability may be needed to more accurately reproduce the experimental diffraction data.

Finally, for compositions in the range $0.65<x<0.67$, sharp diffraction peaks appear at $8.42,9.63$ and $11.03^{\circ}$ in Figure 4a, that correspond to interplanar distances of $2.815,2.463$ and $2.151 \AA$, respectively. These peaks can be indexed using the monoclinic cell that was proposed for $\mathrm{O}^{\prime} 3-\mathrm{Na}_{2 / 3} \mathrm{VO}_{2} .{ }^{10} \mathrm{How}-$ ever, broad diffraction peaks in the $2 \theta$-ranges $9.5-10^{\circ}$ and 11 $12^{\circ}$ are still visible indicating that the structure of $\mathrm{O}^{\prime} 3$ $\mathrm{Na}_{2 / 3} \mathrm{VO}_{2}$ formed during the electrochemically activated P'3 $\rightarrow$ O'3 transition likely contains significant P'3-type stacking defects. This may explain why a transformation back to P'3$\mathrm{Na}_{1 / 2} \mathrm{VO}_{2}$ is still realized once sodium ions are again deintercalated, whereas the electrochemical deintercalation from defect-free O'3- $\mathrm{Na}_{2 / 3} \mathrm{VO}_{2}$ leads instead to O'3- $\mathrm{Na}_{1 / 2} \mathrm{VO}_{2}$. 


\subsubsection{Irreversible transformations}

For compositions in the electrochemically traversed $\mathrm{Na}_{\mathrm{x}} \mathrm{VO}_{2}$ phase diagram with $x \geq 0.67$, the electrochemical curve shows a long voltage plateau related to a two-phase domain. As the same time, diffraction peaks belonging to $\mathrm{O} 3-\mathrm{NaVO}_{2}$ appear at $4.4^{\circ}, 8.8^{\circ} 9.25^{\circ}$ and $9.6^{\circ}$, and their intensity gradually increases upon sodium intercalation. At the end of the discharge, $\mathrm{O} 3-\mathrm{NaVO}_{2}$ predominates with a small amount of a secondary phase that can be assigned to O'3- $\mathrm{Na}_{2 / 3} \mathrm{VO}_{2}$. These data show that the electrochemically activated transitional path from P'3 $\rightarrow$ O'3 ultimately leads to the formation of $\mathrm{O} 3-\mathrm{NaVO}_{2}$ at the end of the sodium electrochemical intercalation. The transition is irreversible, since the reverse path, i.e. electrochemical deintercalation from $\mathrm{O} 3-\mathrm{NaVO}_{2}$, leads to O'3- $\mathrm{Na}_{1 / 2} \mathrm{VO}_{2}$ and not P' $3-\mathrm{Na}_{1 / 2} \mathrm{VO}_{2}$ as it was shown in a previous study. ${ }^{28}$ These results clarify why the electrochemical curve measured on a battery cell initially containing $\mathrm{P}^{\prime} 3-\mathrm{Na}_{\sim 0.53} \mathrm{VO}_{2}$ powder following a full discharge to $1.5 \mathrm{~V}$ shows a very similar profile at matching voltage and sodium compositions to the electrochemical curve measured on of $\mathrm{O} 3-\mathrm{NaVO}_{2}$ based battery cell (as discussed above and shown in Figure 3(b)). Moreover, the diffraction peaks of $\mathrm{O} 3-\mathrm{NaVO}_{2}$ formed after electrochemically activated P'3 $\rightarrow$ O'3 transition are broader than the initial material $\mathrm{O} 3-\mathrm{NaVO}_{2}$ indicating that an electrochemical grinding may have occurred during the full process (thermally activated O'3 $\rightarrow$ P'3 transition and electrochemically activated P'3 $\rightarrow$ O'3 transition). A smaller size of particles, with a reduction of the

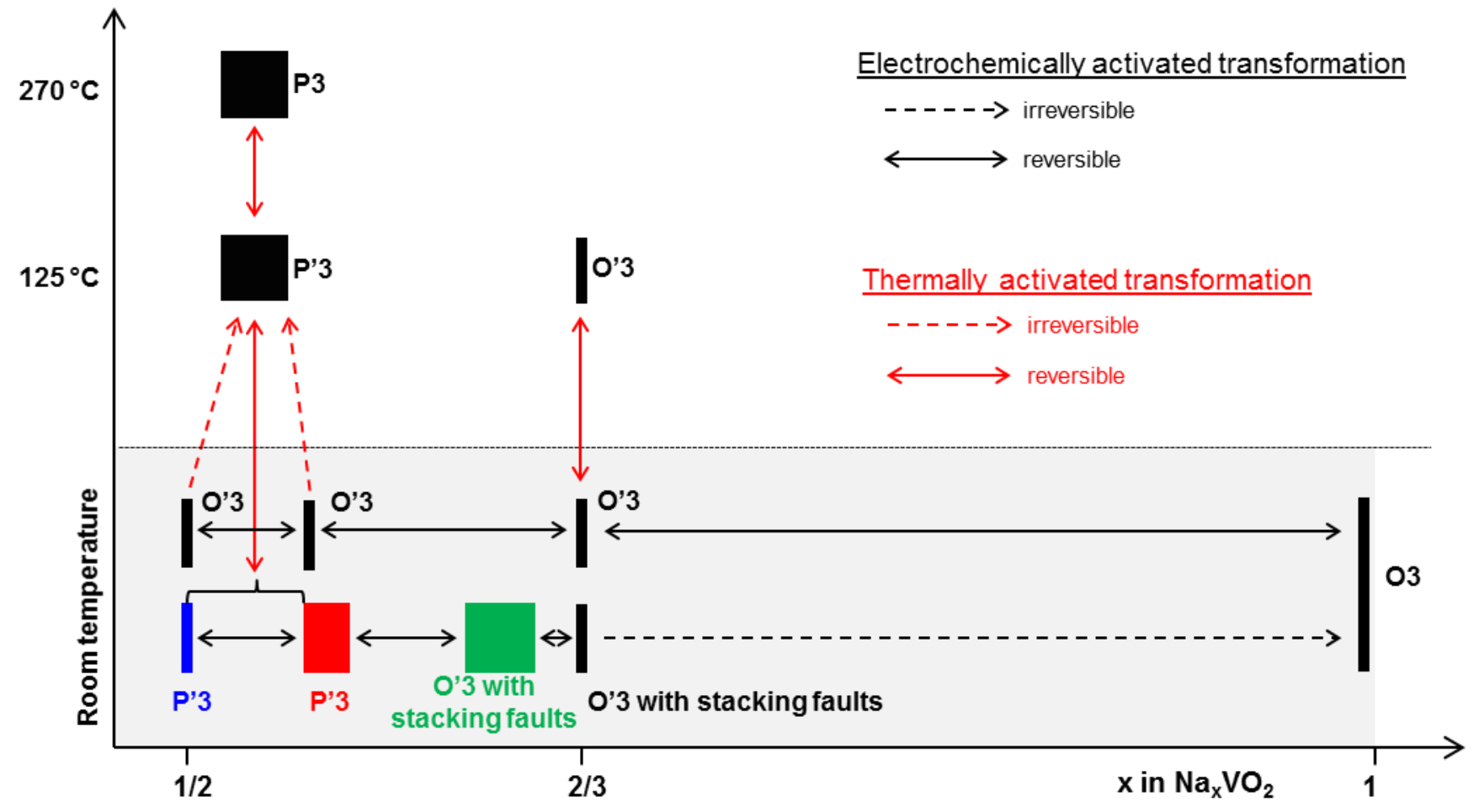

Figure 7. Phase diagram in $\mathrm{Na}_{\mathrm{x}} \mathrm{VO}_{2}$ systems and schematic representation of the thermally and electrochemically driven transformations occurring in these systems reported in this study.

diffusion polarization and an enlargement of the electrochemical surface, could explain why the electrochemical polarization is reduced when comparing the curve recorded from a battery incorporating a $\mathrm{P}^{\prime} 3-\mathrm{Na}_{\sim 0.53} \mathrm{VO}_{2}$ positive electrode material to one using a $\mathrm{O} 3-\mathrm{NaVO}_{2}$ material as is observed in Figure 3(b).

\section{Conclusion}

Figure 7 gives a schematic summary of the thermally and electrochemically driven transformations occurring in sodium layered oxides $\mathrm{Na}_{\mathrm{x}} \mathrm{VO}_{2}$. The new phases reported in this study are shown in blue, red and green. Unlike lithium layered oxides, sodium layered oxides usually undergo many phase transitions during the alkaline ion (de)intercalation. This complexity is the result of either sodium/vacancy ordering arrangements between the $\mathrm{MO}_{2}$ layers due to the larger ionic radius of sodium ions compared to lithium ions, or from the gliding of $\mathrm{MO}_{2}$ slabs as presented in this work. Slab gliding occurs more frequently in sodium layered oxides because the strength of $\mathrm{Na}-\mathrm{O}$ bonds is less than that of $\mathrm{Li}-\mathrm{O}$ bonds. In this work, new metastable phases in the $\mathrm{Na}_{\mathrm{x}} \mathrm{VO}_{2}$ system were obtained by slab gliding using sodium electrochemical (de)intercalation at room temperature which are not accessible by classical synthesis methods. Using in situ and operando high-resolution synchrotron powder diffraction, our work reveals new details of the complex topotactical transformations involving $\mathrm{Na}$ coordination, ordering and defective stacking between $\mathrm{VO}_{2}$ layers which are a backbone for the structural motifs and transformations within $\mathrm{Na}_{\mathrm{x}} \mathrm{VO}_{2}$ and many related sodium layered structures proposed for future electrochemical storage technologies.

\section{ASSOCIATED CONTENT}

Supporting Information. The relationship between hexagonal and monoclinic cells used to describe the structures of the materials studied here is described in the Supporting Information. This material is available free of charge via the Internet at http://pubs.acs.org.

\section{AUTHOR INFORMATION}




\section{Corresponding Author}

* M. Guignard: marie.guignard@icmcb.cnrs.fr.

\section{Present Addresses}

$\uparrow$ CNRS, ICMCB, 87 avenue du Dr A. Schweitzer, 33608 Pessac Cedex, France.

\section{Funding Sources}

Financial support was provided by the CNRS and the Région Aquitaine).

\section{ACKNOWLEDGMENT}

Use of the Advanced Photon Source at Argonne National Laboratory was supported by the U. S. Department of Energy under Contract No. DE-AC02-06CH11357.

\section{REFERENCES}

(1) Huang, Q.; Foo, M. L.; Lynn, J. W.; Zandbergen, H. W.; Lawes, G.; Wang, Y.; Toby, B. H.; Ramirez, A. P.; Ong, N. P.; Cava, R. J. Low temperature phase transitions and crystal structure of $\mathrm{Na}_{0.5} \mathrm{CoO}_{2}$. J. Phys.: Condens. Matter 2004, 16, 5803-5814.

(2) Zandbergen, H. W.; Foo, M.; Xu, Q.; Kumar,V.; Cava, R. J. Sodium ion ordering in $\mathrm{Na}_{\mathrm{x}} \mathrm{CoO}_{2}$ : Electron diffraction study. Phys. Rev. B 2004, 70, 024101.

(3) Viciu, L.; Bos, J. W. G.; Zandbergen, H. W.; Huang, Q.; Foo, M. L.; Ishiwata, S.; Ramirez, A. P.; Lee, M.; Ong, N. P.; Cava R. J. Crystal structure and elementary properties of $\mathrm{Na}_{\mathrm{x}} \mathrm{CoO}_{2}(\mathrm{x}=0.32,0.51$, $0.6,0.75$, and 0.92 ) in the three-layer $\mathrm{NaCoO}_{2}$ family. Phys. Rev. B 2006, 73, 174104.

(4) Berthelot, R.; Carlier, C.; Delmas, C. Electrochemical investigation of the $\mathrm{P} 2-\mathrm{Na}_{\mathrm{x}} \mathrm{CoO}_{2}$ phase diagram. Nature Materials 2011, 10 , 74-80.

(5) Lei, Y.; Li, X.; Liu, L.; Ceder, G. Synthesis and Stoichiometry of Different Layered Sodium Cobalt Oxides. Chem. Mater. 2014, 26, 5288-5296.

(6) Onoda, M. Modulated and unmodulated structures, and the transport mechanisms in the triangular lattice system $\mathrm{Na}_{\mathrm{x}} \mathrm{CoO}_{2}$ with $\mathrm{x}$ $\approx 0.48,0.58$ and 0.65. J. Phys.: Condens. Matter 2008, 20, 145205.

(7) McQueen, T. M.; Stephens, P. W.; Huang, Q.; Klimczuk, T.; Ronning, F.; Cava, R. J. Successive Orbital Ordering Transitions in $\mathrm{NaVO}_{2}$. Phys. Rev. Lett. 2008, 101, 166402.

(8) Jia, T.; Zhang, G.; Zeng, Z.; Lin, H. Q. Orbitally relieved magnetic frustration in $\mathrm{NaVO}_{2}$. Phys. Rev. B 2009, 80, 045103.

(9) Ouyang, Z. W.; Xia, N. M.; Sheng, S. S.; Chen, J.; Xia, Z. C.; Rao, G. H.; Zheng, X. H. Structural distortion and orbital ordering in the triangular-lattice antiferromagnet $\mathrm{NaVO}_{2}$ from first principles. Phys. Rev. B 2011, 83, 094417.

(10) Didier, C.; Guignard, M.; Denage, C. ; Szajwaj, O. ; Ito, S. ; Saadoune, I. ; Darriet, J. ; Delmas, C. Electrochemical NaDeintercalation from $\mathrm{NaVO}_{2}$. Electrochem. Solid-State Lett. 2011, 14, A75-A78.

(11) Hamani, D.; Ati, M.; Tarascon, J.-M. ; Rozier, P. $\mathrm{Na}_{\mathrm{x}} \mathrm{VO}_{2}$ as possible electrode for Na-ion batteries. Electrochem. Commun. 2011, 13, 938-941.

(12) Guignard, M.; Dider, C.; Darriet, J.; Bordet, P.; Elkaïm, E.; Delmas, C. P2- $\mathrm{Na}_{\mathrm{x}} \mathrm{VO}_{2}$ system as electrodes for batteries and electron-correlated materials. Nature Materials 2013, 12, 74-80.

(13) Rüdorff, W; Becker, H. Die Strukturen von $\mathrm{LiVO}_{2}, \mathrm{NaVO}_{2}$, $\mathrm{LiCrO}_{2}$ und $\mathrm{NaCrO}_{2}$. Z. Naturforsch., B: Chem. Sci.1954, 9, 614-615.

(14) Delmas, C.; Fouassier, C.; Hagenmuller, P. Structural Classification and Properties of Layered Oxides. Physica B and C 1980, 99, 81-85.

(15) Delmas, C.; Braconnier, J.-J. ; Fouassier, C.; Hagenmuller, P. Electrochemical Intercalation of Sodium in $\mathrm{Na}_{\mathrm{x}} \mathrm{CoO}_{2}$ Bronzes. Solid State Ionics 1981, 3-4, 165-169.
(16) Braconnier, J.-J. ; Delmas, C.; Hagenmuller, P. Etude par désintercalation électrochimique des systèmes $\mathrm{Na}_{\mathrm{x}} \mathrm{CrO}_{2}$ et $\mathrm{Na}_{\mathrm{x}} \mathrm{NiO}_{2}$. Mater. Res. Bull. 1982, 17, 993-1000.

(17) Komaba, S.; Nakayama, T.; Ogata, A.; Shimizu, T.; Takei, C.; Takada, S.; Hokura, A.; Nakai, I. Electrochemically Reversible Sodium Intercalation of Layered $\mathrm{NaNi}_{0.5} \mathrm{Mn}_{0.5} \mathrm{O}_{2}$ and $\mathrm{NaCrO}_{2}$. ECS Transactions 2009, 16, 43-55.

(18) Han, M. H.; Gonzalo E.; Casas-Cabanas, M.; Rojo, T. Structural evolution and electrochemistry of monoclinic $\mathrm{NaNiO}_{2}$ upon the first cycling process. J. Power Sources 2014, 258, 266-271.

(19) Shannon, R. D.; Rossi, R. C. Definition of Topotaxy. Nature 1964, 202, 1000-1001.

(20) Komaba, S.; Yabuuchi, N.; Nakayama, T.; Ogata, A.; Ishikawa, T.; Nakai, I. Study on the Reversible Electrode Reaction of $\mathrm{Na}_{1-}$ ${ }_{x} \mathrm{Ni}_{0.5} \mathrm{Mn}_{0.5} \mathrm{O}_{2}$ for a Rechargeable Sodium-Ion Battery. Inorg. Chem. 2012, 51, 6211-6220.

(21) Yoshida, H.; Yabuuchi, N.; Komaba, S. $\mathrm{NaFe}_{0.5} \mathrm{Co}_{0.5} \mathrm{O}_{2}$ as high energy and power positive electrode for $\mathrm{Na}$-ion batteries. Electrochem. Commun. 2013, 34, 60- 63.

(22) Wang, X.; Liu, G.; Iwao, T.; Okubo, M.; Yamada, A. Role of Ligand-to-Metal Charge Transfer in O3-Type $\mathrm{NaFeO}_{2}-\mathrm{NaNiO}_{2}$ Solid Solution for Enhanced Electrochemical Properties J. Phys. Chem. C 2014, 118, 2970-2976.

(23) Sathiya, M.; Hemalatha, K.; Ramesha, K.; Tarascon, J.-M.; Prakash, A. S.Synthesis, Structure, and Electrochemical Properties of the Layered Sodium Insertion Cathode Material: $\mathrm{NaNi}_{1 / 3} \mathrm{Mn}_{1 / 3} \mathrm{Co}_{1 / 3} \mathrm{O}_{2}$. Chem. Mater. 2012, 24, 1846-1853

(24) Li, X.; Wu, D.; Zhou, Y. -N.; Liu, L.; Yang, X. -Q.; Ceder, G. O3-type $\mathrm{Na}\left(\mathrm{Mn}_{0.25} \mathrm{Fe}_{0.25} \mathrm{Co}_{0.25} \mathrm{Ni}_{0.25}\right) \mathrm{O}_{2}$ : A quaternary layered cathode compound for rechargeable $\mathrm{Na}$ ion batteries. Electrochem. Commun. 2014, 49, 51- 54.

(25) Mazaaz, A.; Delmas, C.; Hagnemuller, P. A Study of the $\mathrm{Na}_{\mathrm{x}} \mathrm{TiO}_{2}$ System by Electrochemical Deintercalation. J. Inclusion Phenom. Macrocyclic Chem. 1983, 1, 45-51.

(26) Kim, S.; Ma, X.; Ong, S. P.; Ceder, G. A comparison of destabilization mechanisms of the layered $\mathrm{Na}_{\mathrm{x}} \mathrm{MO}_{2}$ and $\mathrm{Li}_{\mathrm{x}} \mathrm{MO}_{2}$ compounds upon alkali de-intercalation. Phys. Chem. Chem. Phys. 2012, 14, 15571-15578.

(27) Szajwaj, O.; Gaudin, E.; Weill, F.; Darriet, J.; Delmas, C. Investigation of the New P' $3-\mathrm{Na}_{0.60} \mathrm{VO}_{2}$ Phase: Structural and Physical Properties. Inorg. Chem. 2009, 48, 9147-9154.

(28) Didier, C.; Guignard, M.; Darriet, J.; Delmas, C. O'3- $-\mathrm{Na}_{\mathrm{x}} \mathrm{VO}_{2}$ System: A Superstructure for $\mathrm{Na}_{1 / 2} \mathrm{VO}_{2}$. Inorg. Chem. 2012, 51, 11007-11016.

(29) Petricek, V.; Dusek, M.; Palatinus, L. Crystallographic Computing System JANA2006: General features. Z. Kristallogr. 2014, $229,345-352$.

(30) Saadoune, I.; Maazaz, A.; Ménétrier, M.; Delmas, C. On the $\mathrm{Na}_{x} \mathrm{Ni}_{0.6} \mathrm{Co}_{0.4} \mathrm{O}_{2}$ System: Physical and Electrochemical Studies. $J$. Solid State Chem. 1996, 122, 111-117.

(31) Lang,G.; Bobroff, J.; Alloul, H.; Collin, G.; Blanchard N. Spin correlations and cobalt charge states: Phase diagram of sodium cobaltates. Phys. Rev. B 2008, 78, 155116.

(32) Feyerherm, R.; Dudzik, E.; Valencia, S.; Wolter, A. U. B.; Milne, C. J.; Landsgesell, S.; Alber, D.; Argyriou, D. N. Transition from a phase-segregated state to single-phase incommensurate sodium ordering in $\gamma-\mathrm{Na}_{\mathrm{x}} \mathrm{CoO}_{2}(\mathrm{x} \approx 0.53)$. Phys. Rev. B 2010, 82, 024103.

(33) van Smaalen, S. Incommensurate Crystallography; Oxford University Press, 2007.

(34) Blangero, M. ; Carlier, D. ; Pollet, M. ; Darriet, J. ; Delmas, C. ; Doumerc, J.-P. High-temperature phase transition in the threelayered sodium cobaltite P' $3-\mathrm{Na}_{\mathrm{x}} \mathrm{CoO}_{2}(\mathrm{x} \sim 0.62)$. Phys. Rev. B $\mathbf{2 0 0 8}$, 77, 184116.

(35) http://www.public.asu.edu/ mtreacy/DIFFaX.html. 


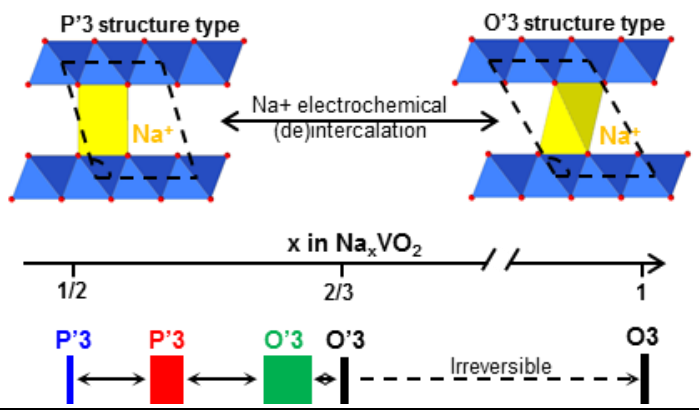

